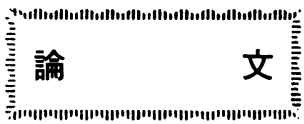

\title{
一石他励インバータによる 非常照明用点灯回路の効率改善
}

\author{
専門会員 井山 博之* 専門会員 赤塚 美津雄** \\ Efficiency Improvement of Emergency Lighting Circuit by Separately \\ Excited One Transistor Inverter
}

Hiroyuki Iyama (Fellow Member)

(Central Research Labo. Hitachi Ltd.)

Mitsuo Akatsuka (Fellow Member)

(Hitachi Lighting Ltd.)

\begin{abstract}
Efficiency improvement of a fluorescent lamp driving inverter for emergency lighting use is described. a separately excited one transistor inverter is applied to the $36 \%$ luminous flux system of a 20 watt lamp. A Darlington circuit was bridged with a coil to reduce the switching and driving losses in the transistor switch circuit. For effective use of battery energy, the input power to the lamp is kept constant by controlling the switching duty cycle against the change of source voltage. Two kinds of load circuits, direct current type and capacitance ballast type are studied.

Consequently, an efficiency better than $83 \%$ and constant power characteristics are achieved in the prototype circuits.
\end{abstract}

\section{1. は じめに}

ビル火災のような非常時に, 主電源が切られた後も点灯を維持 して非常口，避難路を示し，消火活動などを容易にするための非 常用照明は，消防法および建築基集法で設置基準が決められ，義 務づけられている.この非常照明用点灯回路は器具内蔵電池を電 源とし，高周波インバータにより汁い光ランプを点灯する回路方 式が主流をなしている.内藏䉓池として用いるニッケル・カドミ ウム電池は 1 セル当たりの定格電生 $1.2 \mathrm{~V}$, 定格電流 $1.2,1.65$, 1.8あるいは3.5アンペア・時のものを, 複数個直列に接続したも のである.この電池は 1 七ル当たりの価格が高く, しか子器具に 比べて寿命が短い.したがって使用電池七ル数は少ないことが望 ましく，そのためには高効率動作可能な点灯回路が要求されてい る.

本報告は, $20 \mathrm{~W}$ けい光ランプ FL $20 \mathrm{~S}$ を $36 \%$ 光束で点灯する 誘導灯用インバータを対象に行なった回路効率改善の検討結 果 ${ }^{1) \sim 3}$ に関するものである.

\section{2. 高効率化のための基礎検討}

FL20S，36\%光束用インバータの従来品（日立製）はプッシュ プル方式で, 1.2 アンペア・時 $(\mathrm{A} / \mathrm{h})$ 電池 7 セルを用いておりイ

\footnotetext{
* 日立製作所中央研究所

** 日立照明

本論文の一部は昭和 54 年度および55年度照明学会全国大会, および電気学会光地 用・視覚研究会 LAV-80-17 で発表済み.
}

ンバータ効率は $71 \%$ 程度である。このように効率が低いのは，電 源電圧が低く入力電流が大きいために，スイッチング損失の比率 が大きいことによる．従来品で電池 1 セルを低減するには $83 \%$ 以 上のインバータ効率を実現する必要がある。

そこで高効率動作のための目標として次の 2 項を設定した.

(1) インバータ効率を $83 \%$ 以上にする.

（2）電源電圧の変化に対して定電力特性を得ることにより，電 池エネルギー（あるいは $\mathrm{A} / \mathrm{h}$ 容量值）の利用効率を高める.

電池セル数低減のための高効率インバータ回路の基本構成を図 1 に示す. ランプ負荷回路は，(1)直流点灯方式と(口)交流点灯方式 の 2 方式について 検討した。発振回路部分は共通である. 動作 は, $20 \mathrm{kHz}$ の矩形波発振器 $\mathrm{AMV}$ 出力を補助トランジスタ $Q_{2}$ に より增幅して主トランジスタ $Q_{1}$ をオンオフ制御する。この動作

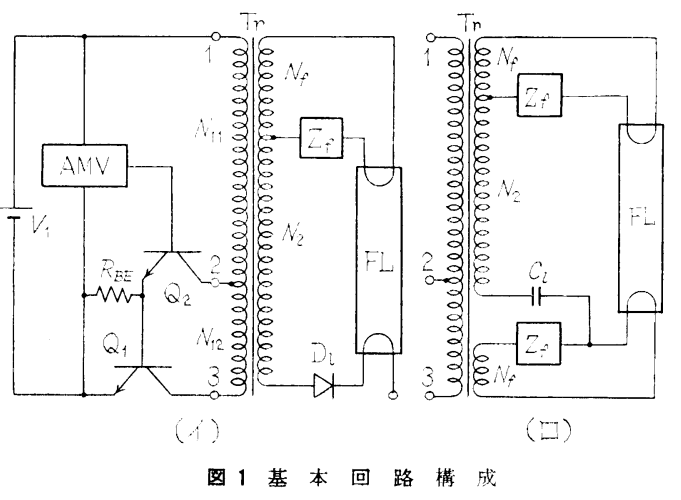


により，トランス $\operatorname{Tr}$ の一次コイルに発生する高周波電圧を昇圧 してけい光ランプ FLを点灯する. 定電力特性は電源電圧の変化 に応じて AMV の発振状態を変化させることにより得る.

以下, 因 1 の構成に適用した高効率動作のための基本事項につ いて述べる.

\section{1 インバータ回路損失の低減}

従来回路で低減可能な回路損失の主なものは, スイッチング損 失とドライブ回路損失であり, 下記の 3 項目を考虑して回路を構 成した。な拉トランス $\operatorname{Tr}$ の損失も重要であるが，今回の検討で は鉄損の小さなコア材質を選定するにとどめた。

(1) 一石インバータ方式を用い, ターンオン, ターンオフ動作 による損失を小さくする.

（2）補助巻線 $N_{12}$ を介したダーリントン接続を採用して，オン 状態電圧降下によるトランジスタ損失と, ドライブ回路損失を最 小にする.

（3）矩形波発振器による矩形波他励方式を採用する.

(1)項は, スイッチング損失の約 $1 / 2$ を生じるオン・オフ動作の 一周期当たりの回数を少なくすることを目的とし，一石方式はプ ッシュプル方式の $1 / 2$ の回数である. またスイッチング電流波形 も重要で, オン・オフスイッチング時の電流瞬時値を小さく整形 する必要がある. そのためには一周期における $Q_{1}$ のオン期間の 比率 (duty Cycle) の大きい矩形波に近づける.

(2)項に関しては, 通常のダーリントン接続ではオン状態でのコ レクタ・エミッタ間飽和電圧が高くなることが知られている。

$N_{12}$ を介してダーリントン接続にすると，トランジスタ $Q_{1}$ の飽 和電圧 $V_{C E 1}$ は $N_{12}$ の電圧 $V_{N 12}$ を加えることにより, (1)式のよ $5 に Q_{1}$ 単独で用いる場合の值にまで低減できる.

$$
V_{C E 1}=V_{B E 1}+V_{C E 2}-V_{N 12}
$$

ここに, $V_{B E 1}$ は $Q_{1}$ のベース・エミッタ間の順方向電任, $V_{C E 2}$ は $Q_{2}$ のオン状態でのコレクタ・エミッタ間電圧である. またド ライブ回路損失 $W_{D}$ は $Q_{1}$ のベース電流を $I_{B}$ とし, duty cycle をDとして(2)式で近似される.

$$
W_{D} \fallingdotseq I_{B} \cdot\left(V_{N 12}+V_{C E 1}\right) \cdot D \cdot
$$

(2)式では $N_{12}$ は小さいほど $W_{D}$ が小さくなるが，(1)式との関係 で効率最大となる $N_{12}$ の值がある.

ダーリントン接続では, 逆バイアスによるスイッチオフ動作が できないため， $Q_{1}, Q_{2}$ には高周波用トランジスタを用い，抵抗 $R_{B E}$ の接続によりターンオフ時間を短縮する. さらに主トラン ジスタ $Q_{1}$ はコレクタ・エミッタ間飽和電圧が小さいことが重要 である. 前記(3)項は $Q_{1}$ のコレクタ電流波形に近いベース電流波 形でドライブすることを目指している.

\section{2 負荷回路の検討}

\section{(1) 直流点灯方式}

点灯回路は図 1 (イ）である. 周知のようにランプ始動時, 陰 極となる側の電極は予熱が必要であるが，陰極が片側に固定され る直流点灯の場合は予熱回路は 1 個でよく, 点灯中の予熱損失が 小さい. 動作はスイッチングレギュレータと同じ動作で, 主トラ ンジスタ $Q_{1}$ のオフ期間にだけランプ電流が流れる.

けい光ランプを直流点灯すると, 水銀イオンの偏りによって管 壁輝度のアンバランス，すなわちカタホレシス現象が生じること が知られている.

図 2 はカタホレシス発生所要時間の実側值の例である.この

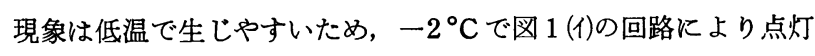
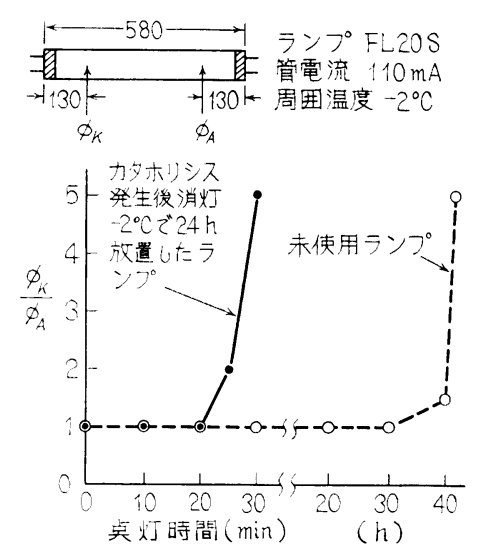

图 2 カタホレンスの発生

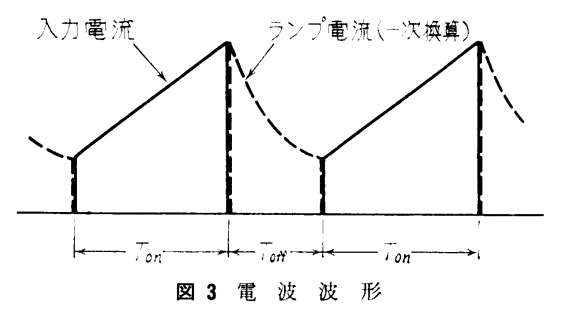

し, アノード側とカソード側の管端から $13 \mathrm{~cm}$ の点の光束 $\phi_{\boldsymbol{A}}, \phi_{\boldsymbol{K}}$ を測定して得た。動作電流波形を図 3 に示す.

未使用ランプでは，最初にカタホレシスが生じるまでの所要時 間は40時間であり，一度カタホレシスが生じたランプでも24時間 放置すると, 再びカタホレシス状態になるまでの時間は20分以上 である. 非常用照明は点灯維持時間が $25 〜 37$ 分で短く, 点灯ひん 度が小さいため, カタホレシス現象はこの場合ほとんど問題にな らないと考えてよい.

図 3 に示すようにランプ電流は直流パルス状に流れる。矩形波 パス点灯の場合のけい光ランプ発光率は，正弦波電流高周波点 灯方式に比べて低下しないとされている4)が，波形が異なるため 確認試験を行なった. 光束はランプ中央部の光束を簡易形照度計 で測定した值を用い, ランプ電力は電圧電流波形からシンプソン の公式により計算した值を用いて比較した結果, 正弦高周波点灯 に比べて $5 \%$ 程度の誤差の範囲で差が無いことがわかった.

これらの結果から，少なくとも平常時は商用電源により交流点 灯される誘導灯用としては, 直流点灯方式は交流点灯方式と同様 に適用可能であると考觉られる.

\section{(2) 交流点灯方式}

コンデンサバラスト方式による交流点灯回路は, 図 1 (口)に示し た.この方式は電極予熱回路は 2 個であるが，トランジスタ $Q_{1}$ のコレクタ電流波形を矩形波に近づることが可能なため, 高効 率動作が可能である. 図 1 (ロ)で予熱回路と $Q_{2}$ を除き, ランプを 等価抵抗で置換して一次換算した值を $R_{L}$, 一次換算したバ トコンデンサ $C_{l}$ の容量を $C_{L}$, 一次コイルインダクタンスを $L_{1}$, 入力電圧を $V_{1}$ とすればュレクタ電流 $i_{c}$ は(3)式で表わされる.

$$
i_{c}=\left(\frac{V_{1}}{L_{1}} t+I_{0}\right)+\left(\frac{V_{1}+V_{0}}{R_{L}} e^{-\frac{t}{C_{L} R_{L}}}\right)
$$

$I_{0}, V_{0}$ は $L_{1}$ の励磁電流と $C_{L}$ 電圧の初期值である. $i_{c}$ 波形の合 成を 図 4 に示す. $i_{11}$ は直線的に増加する励磁電流成分で, $i_{12}$ は $C R$ 減衰波形となる負荷電流成分である. 各定数を調整するこ とにより実線で示した $i_{c}$ 波形を矩形波に近似できる. しかし最 適 $i_{c}$ 波形の場合のバラストコンデンサ $C_{l}$ の容量値は, 放電電流 安定化のための值と一致しないことも考えられる. そのため放電 


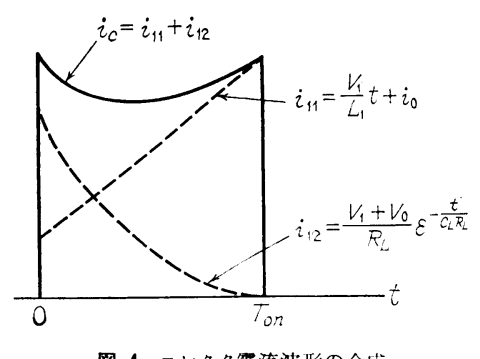

图 4 コレタタ電流波形の合成

電流安定化は，矩形波発振器 AMVの duty cycleを帰還制御す ることで補助する。

\section{3 電池のアンペア・時利用効率の向上}

非常用照明では, 電池の光束標準電圧 $(1.1 \mathrm{~V} /$ セル) 以上で所 定の值以上の光束を保証する必要がある．従来のインバータ回路 では，入力電流が電源電圧の変化に対してほぼ平担な特性になっ ている. 1 セルの電池を定格電流 1 Cアンペアの一定值で放電し たときの電池電圧 $V_{B 1}$, 電流 $I_{B 1}$ の経時变化を 图 5 に示す.

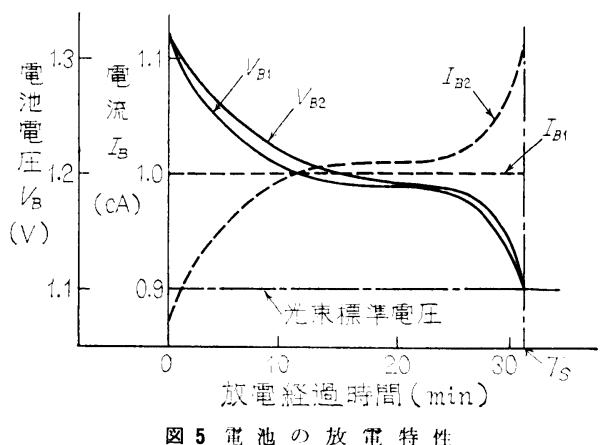

電圧は光束標準電圧に達するまでの変化が $20 \%$ 以上に及が. $V_{B 2}, I_{B 2}$ は放電電力を一定にして放電した場合の電圧電流変化で ある. 電池のアンペア・時 $(\mathrm{A} / \mathrm{h})$ 值を一定と考光, $V_{\boldsymbol{B} 2}$ が光束 標準電圧に達するまでの時間 $T_{S}$ は $V_{B 1}$ の場合と同じとし， $I_{B 2}$ の $T_{S}$ までの時間積分值は $I_{B 1}$ のそれに等しく描いている.この 図から明らかなように，時刻 $T_{S}$ における $I_{B 2}$ の值は $I_{B 1}$ より大 きくなるため, 光束標準電圧以上で所定の光束值を保証するため のインバータ効率は, 定電力特性の場合, 従来の定電流特性の場 合に比べて低くてょいすすなわち定電力特性にすれば電池の $\mathrm{A} / \mathrm{h}$ 值の利用効率が高くなり，インバータ効率向上と同じ効果が期待 できる。

電源電圧の変化に対して定電力特性を得るためには, 電源電圧 の変化に応じて duty cycle を変化する方式 ${ }^{5)}$ をいた. 直流点 灯方式の場合について $Q_{1}$ のオン期間 $T_{o n}$, オフ期間 $T_{\text {off }}$ (図 3 参照）と入力電力 $W_{1}$ の関係を求めると(4)式のようになる．等価 回路拈よび回路定数を図 6 (イ）に示した.

$$
W_{1}=\frac{1+e^{-\frac{R_{L}}{L_{1}} T_{o f f}}}{1-e^{-\frac{R_{L}}{L_{1}} T_{o f f}}} \cdot \frac{\left(T_{o n}\right)^{2}}{T_{o n}+T_{o f f}} \cdot \frac{V_{1}^{2}}{2 L_{1}}
$$

$R_{L} ， L_{1}$ を図 $6\left(\right.$ (1)の值に選び 1 周期を $50 \mu \mathrm{S} ， V_{1}$ をパラメータと したときの duty cycle と, 入力電力との関係の(4)式による計算 結果を図6(口) に示す. たとえば， $V_{1}$ が $7.8 \mathrm{~V}$ から $6.6 \mathrm{~V}$ に 16\%小さくなったとき duty cycle を約 $11 \%$ 大きくすれば，定電 力特性が得られることがわかる.

コンデンサバラストによる交流点灯方式の場合も同様に, duty
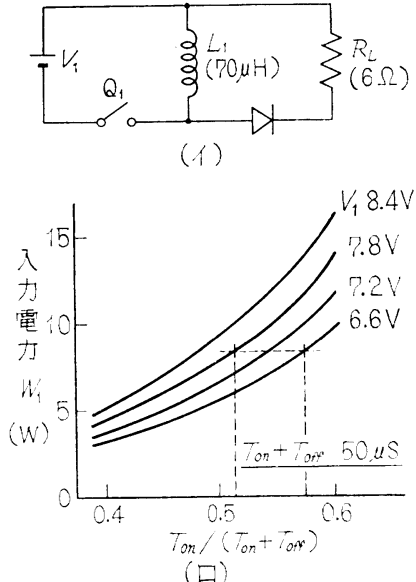

图 6 duty cycle による電力の変化 (1) 直流点灯回路の等価回路 (a) duty cycle と電力の関俰

cycle の変化により定電力特性を得る.

\section{3. 矩形波発振回路}

矩形波発振回路 AMV は, 電源電圧によって duty cycle が 変化することが必要である. そのための方法として一定ゲート電 圧で, High レベル $\left(H_{i}\right) \rightleftarrows L_{o w}$ レベル $\left(L_{o}\right)$ の切り替えが生じる ロジックインバータのゲートを，1個のコンデンサの充放電を用 いて制御する回路を検討した。

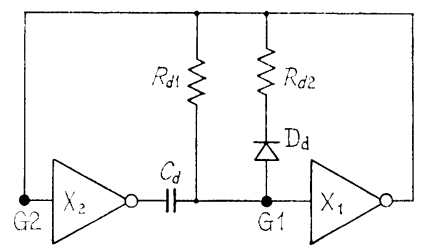

图 7 矩形波発捈器基本構成

図 7 亿基本構成を示す. $X_{1}, X_{2}$ はロジックインバータであり トランジスタ・トランジスタロジック $T T L$ を用いた.

動作は $X_{1}$ のゲート端子 $G_{1}$ が $L_{0}$ のとき $X_{1}$ 出力，すなわち $G_{2}$ 端子は $H_{i}$ で $X_{2}$ 出力は $L_{0}$ である. よってコンデンサ $C_{d}$ は 抵抗 $R_{d 1}$ を通して充電され， $G_{1}$ 端電圧は徐々に上昇し， $V_{t h} に$ 達したとき $X_{1}$ 出力は $L_{0}$ になる。 したがって $G_{2}$ 端は $L_{0}, X_{2}$ 出 力端は $H_{i}$ になるため， $G_{1}$ 端電位はさらに高くジャンプし， $X_{1}$ 出力端は $L_{0}$ を保持する. その後 $C_{d}$ は $R_{d 1}, R_{d 2}$ を通して放電 し， $G_{1}$ 端電位が $V_{t h}$ に低下したとき $X_{1}$ 出力端は $H_{i}, X_{2}$ 出力 端は $L_{0}$ に変化する. そのため $G_{1}$ 端電位はさらに低くジャンブ し最初の状態に戻る. この動作をくり返して持続発振を行なら。

$X_{1}$ 出力端が $H_{i}$ の期間 $T_{H}$ と $L_{0}$ の期問 $T_{L}$ を求めるための等 価回路を 図 8 (イ)に示した. $V_{c c}$ は $T T L$ の電源電圧, $R$ は口 ジックインバータ出力が $H_{i}$ のとき，出力と直列にはいるロジッ クインバータの内部抵抗である. TTL のゲートは負方向電圧を ダイオートでクリップする構成となっており，このダイオードの 順方向電圧を $V_{D S}$ とした． $T_{H}, T_{L}$ は(5)，(6)式で表わされる.

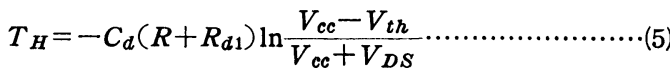

$$
\begin{aligned}
& T_{L}=-C_{d}\left(R+R_{L 0}\right) \ln \frac{V_{t h}\left(R+R_{L 0}\right)}{\left(V_{t h}+V_{c c}\right) R_{L 0}} \ldots \ldots \ldots \ldots \ldots \ldots(6)
\end{aligned}
$$

ここに, $R_{L 0}$ は $R_{d 1}$ と $R_{d 2}$ の並列合成抵抗值 $\left(R_{d 1} \cdot R_{d 2} /\left(R_{d 1}+\right.\right.$ 


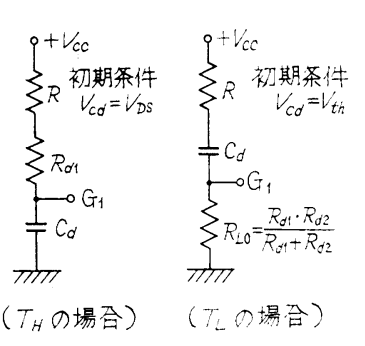

(1)
图 8 䉓源電印による duty cycle の変化

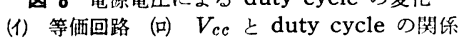

$\left.R_{d 2}\right)$ ) である. 因 $8\left(\right.$ 口) に計算例を示す. $T T L$ の電源電圧 $V_{c c}$ が高くなると duty cycle $\left(T_{H} /\left(T_{H}+T_{L}\right)\right)$ は低下することがわ かる. $V_{c c}$ が $5.5 \mathrm{~V}$ から $4.5 \mathrm{~V}$ に20\%低下すると, duty cycle は 約 $17 \%$ 增加する.

\section{4. 直流点灯回路}

直流点灯回路の主回路と矩形波発振回路 AMV の構成を 図 9 に示寸. 電池 $V_{1}$ は $1.2 \mathrm{~A} / \mathrm{h} 6$ セル $(7.2 \mathrm{~V})$ で, 従来品より 1

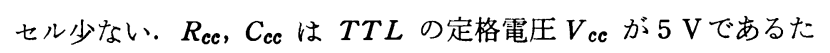
め, 電圧調整のために接続した. $C_{0}$ は無負荷動作時の 電圧制限 用のコンデンサであり, ダイオード $D_{f}$ は点灯中の電極予熱損失 を抑えるためのものである. $Q_{1}$ のコレクタと AMV 回路端子 $C$ との接続はコレクタ電圧を州還して, 負荷変動による入力電力の 变動を抑えるためのものである. $N_{s}, C_{s}$ の回路は $N_{2}$ の巻数を最 大効率とするように決めたとき，始動時に $N_{2}$ に発生する電圧が ランプのブレークオーバ電压に満たないことも考えられ, その場 合でも十分な電圧をランプに印加するために設けた。，点灯中 $C_{s}$ を流れる電流が大きいと効辫低下をきたすので，Cs 限の容量とする.
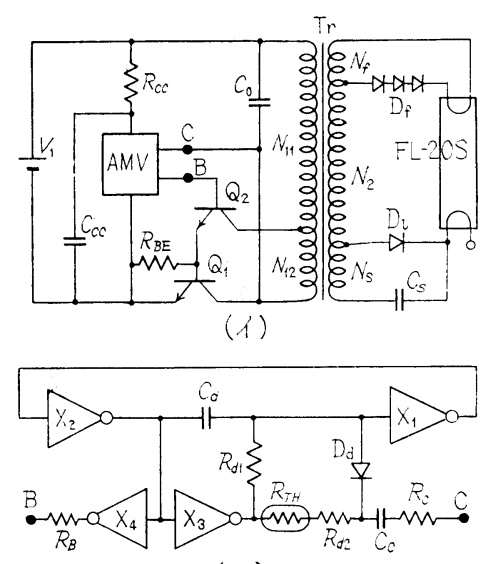

(ㅁ)

因 9 直流点灯回路

(1) 主回路構成 (ㅁ) AMV 回路

図 9 (ロ) に矩形波発振回路 AMV の構成を示す. 図 7 との違い は, コンデンサ $C_{d}$ の充放電回路の他端をロジックインバータ $X_{3}$ の出力端に接続したこと, 㷌還回路 $C_{c}, R_{\mathrm{c}}$ を接続したことであ るが, 発振動作は図 7 の場合と変わらない， $R_{T H}$ は温度補償用 のサーミスタである. $Q_{2}$ のベース入力は $X_{4}$ の出力端電圧であ り,この電圧が $H_{i}$ のときは $Q_{2}, Q_{1}$ はオン状態となる. この接 続に打いて $V_{1}$ の電圧が高いほど $Q_{1}$ の duty cycle が小さくな り, 定電力特性を実現することが可能である.
図 9 の回路定数例 は, 電源 $V_{1}$ の定格電圧が $7.2 \mathrm{~V}, Q_{1}$ には $2 \mathrm{SC} 2092 ， Q_{2}$ は $2 \mathrm{SD} 763$ (日立) を用い，トランス $T_{r}$ 用コア は SB-5 EI-28 (日本フェライト)を用いた. AMV 用の $T T L$ は HD 7400 (日立) を用い, 点灯中の発振周波数は $20 \mathrm{kHz}$ 程度 である.

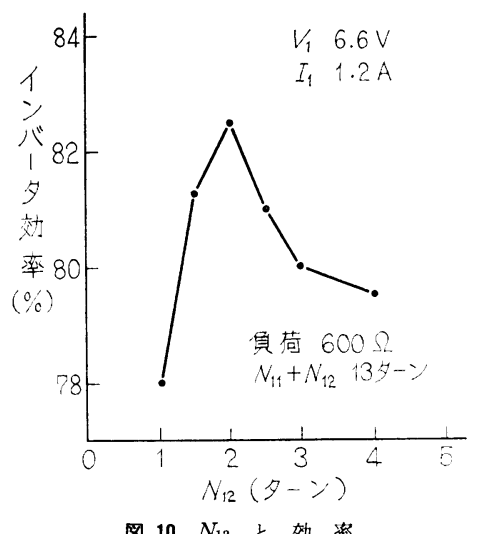

图 $10 N_{12}$ と効率

図 10 亿補助巻線 $N_{12}$ とインバータ効率の関係を示す.負荷は $600 \Omega$ の抵抗負荷を用い, 一次コイル総巻数は13ターン, 一次コ

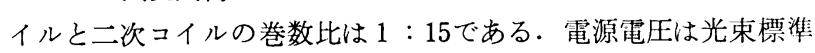
電圧の $6.6 \mathrm{~V}$, 入力電流を $1.2 \mathrm{~A}$ としたとさのインバータ効率の 実測值をプロットした. 補助巻数 $N_{12}$ は 2 ターンのとき最大効率 を示す. トランス $T_{r}$ の巻数を変化する場合は $N_{11}$ と $N_{12}$ との卷 数比をこの場合と同じ值に保てばよい. $N_{12}$ が 0 ターンの場合が 通常のダーリントン接続の場合である.

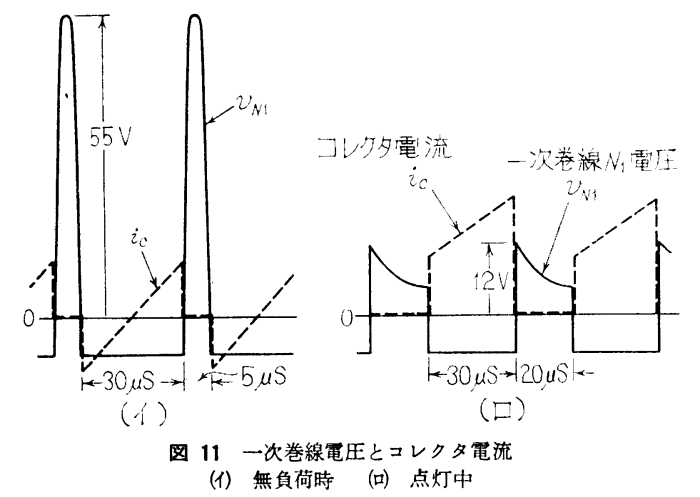

図1の予熱回路インピーダンス $Z_{f}$ としては, 従来のプッシュ プル方式の場合はコンデンサを用い, 直列共振条件を利用して, 点灯中の電極予熱損失を極力小さくしている. 一石インバータの 場合は, 一次コイル $N_{1}\left(N_{11}+N_{12}\right)$ 両端電圧波形が図 11 のよう にパルス状であり，正弦波とならないために共振を利用する方法 は効果が少ない．しかし図11に示したように点灯中の $N_{1}$ 両端電 圧ピーク值は無負荷時の約 $1 / 5$ にまで低下するため, この差電圧 を用いてランプ始動時にたけけ十分な予熱電流を流し, 点灯中の予 熱電流を無視できる值にまで低減できる.図9の連結ダイオード $D_{f}$ がそのための回路で, ダイオードの順方向電圧により負荷時 と点灯中の差電圧を検知して予熱動作を行なう.このため予熱巻 線 $N_{f}$ は必要最小限の巻数にして， $D_{f}$ のダイオード個数を最少 にする.

トランス $T_{r}, C_{0}, R_{B E}$ など, 四 9 に打けるその他の回路定数 の最適条件を検討して試作した回路の点灯特性を図 12 亿示す. 予熱損失を損失とした場合のインバータ効率は $83 \sim 84 \%$, 光束標 準電圧6. $6 \mathrm{~V}$ に括ける比光束は $38 \%$ であり, 規格の $36 \%$ 以上を満 
足している. 比光束のカーブはゆるやかではあるが正特性を示 し, 定電力特性は十分でない，入力電流は負特性で定格電圧 7.2

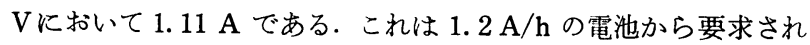
る電流上限值 1.2 A以下を満たしている.

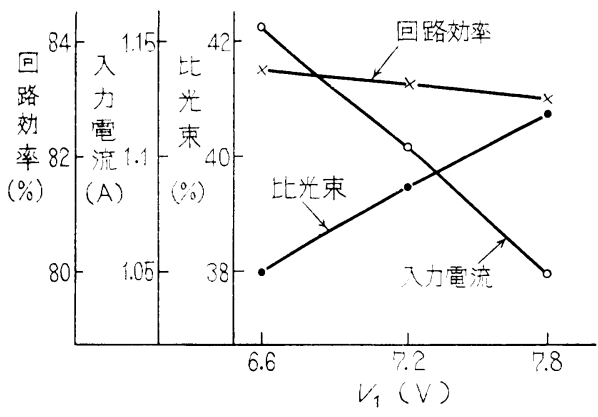

図 12 直流点灯試作回路の特性

以上のように図 9 の直流点灯回路により, 従来回路における電 池 7 セルから 6 セルへ 1 セル低減するに十分な特性を得た。

\section{5. 交流点灯回路}

コンデンサバラストによる交流点灯回路の構成を 図 13 に示 す.
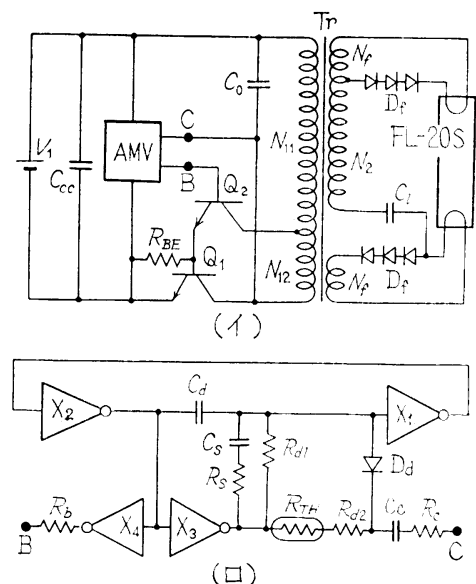

( $\square)$

图 13 交流点灯回路

(1) 主回路構成 (口) AMV 回路

この場合は $1.8 \mathrm{~A} / \mathrm{h}$ 電池 4 セル化を目標に検討を進めた. 電池 の定格ボルト・アンペア值は $1.2 \mathrm{~A} / \mathrm{h}$ 電池 6 セルの場合と同じで ある. 電源電圧 $V_{1}$ は $4.8 \mathrm{~V}$ であり, $\mathrm{AMV}$ 回路の電圧調整回路 は不要である. 負荷回路は交流動作であるため, 両電極の予熱回 路を必要とする. 直列ダイオード $D_{f}$ は直流点灯回路の場合と同 じ動作をする. AMV 回路は電源電圧の変化に対して定電力特性 を増すために, $R_{d 1}$ と並列にコンデンサ $C_{s}$ と抵抗 $R_{s}$ の直列回 路を設けた。

コンデンサバラスト方式を用いる目的は, 点灯中のコレクタ電 流 $i_{c}$ 波形を矩形波に近づけ，スイッチング損失を低減すること である. 図 4 で示したように定数の選び方により $i_{c}$ 波形が 変化 する. 図 14 にバラストコンデンサ容量 $C_{l}$ を变化した場合の発 光効率の変化を示す. パラメータは一次総巻数 $N_{1}$ に対する二次 巻数 $N_{2}$ の巻数比である. 効率はランプ中央部の相対光束 $\phi$ と入 力電力 $W_{1}$ との比率により求めた. 条件は $V_{1} 4.4 \mathrm{~V}$ 入力電流 $1.7 \mathrm{~A}$ 扰よびトランジスタ $Q_{1}$ のオン期間 $T_{o n} 28 \mu \mathrm{S}$ 一定とし た.

$C_{l}$ が小さいと $Q_{1}$ のターンオン直後の電流値が大きく, $C_{l}$ が

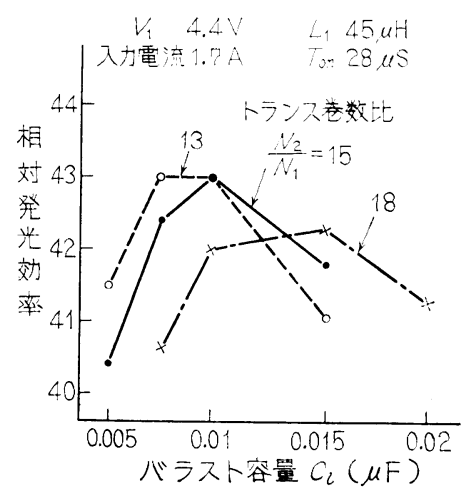

図 14 バラスト容最と効率

大きいとターンオフ值前の電流值が大きいため, それぞれターン オン時, ターンオフ時の損失が大きくなる傾向であり, それらの 中間の容量で最大効率を示す.

巻数比が小さいほど効率最大となる $C_{l}$ 最適容量值は小さくな る. 巻数比が大きすぎると最大効率值が低下する傾向である，巻 数比下限はランプ始動電圧によって決まる.

コンデンサバラストの場合, 直流点灯方式に比べて, トランス $T_{r}$ の負荷にリアクタンス成分が加わるため, duty cycle の変化 に対する定電力特性化の割合が小さくなる，そのため $C_{s}, R_{s}$ を接 続して duty cycle の変化を大きくする.

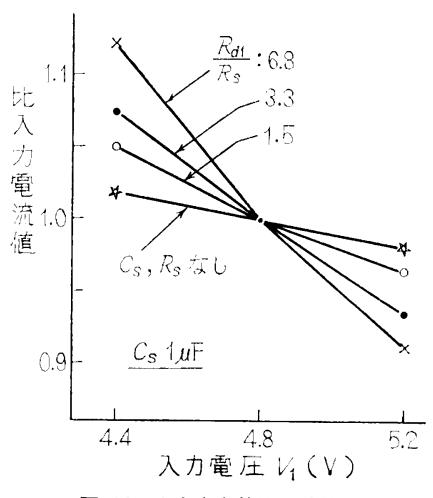

図 15 入力変動特性の改善

図 15 に $R_{s}$ と $R_{d 1}$ の比率を変えた場合の入力電流変化を示 す. $C_{s}, R_{s}$ を接続しない場合は $V_{1} 4.4 \mathrm{~V}$ から $5.2 \mathrm{~V}$ の変化で数 \%変化しか得られないが， $R_{d 1} / R_{s}$ を6.8にすると $20 \%$ の変化が生 じる. コンデンサ $C_{8}$ はバイアス電圧を与えるために挿入し， あ る值以上であれば容量値には関係しない，定電力特性は $R_{d 1} / R_{s}$ が3.3〜4.7のとき得られた.

図13の各回路定数の最適値を検討して試作した回路の各部波形 を図 16 に示す. (1)のスイッチング波形は $Q_{1}$ のターンオン時に ピーク電流が流れているが，他はほぼ理想的な波形となってい る. (口)のランプ電圧, 電流波形はバラストインピーダンスが小さ いため正弦波とはならない

点灯特性をに图 17 示す. 定電力 (光出力) 特性は直流点灯の 場合よりさらに良好になっている. 予熱回路損失を損失に含めた 回路効率は $84 \%$ 以上であり, 従来品に比べて $10 \%$ 以上の上昇を得 ている. 定格電圧 $4.8 \mathrm{~V}$ に抢ける入力電流は $1.65 \mathrm{~A}$ (目標は 1.8 A以下）で，光束標準電圧 $4.4 \mathrm{~V}$ に怙ける比光束は $37.7 \%$ （規格 は36\%以上）である.

以上のように図13の交流点灯回路により，1.8 A/h 電池 4 セル 化が十分可能な特性を得た. 


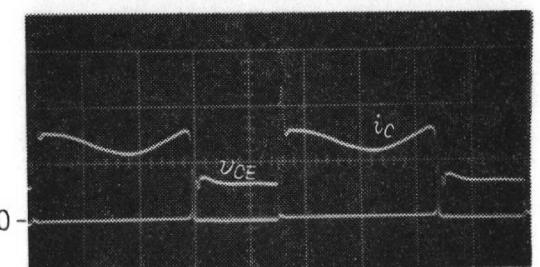

\section{$(1)$}

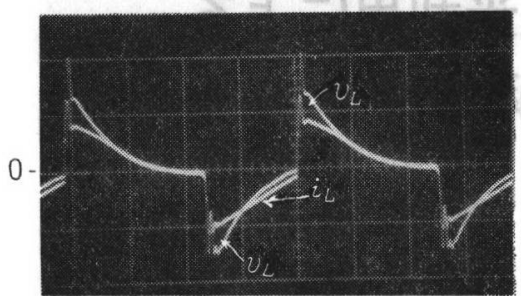

(ㅁ)

图 16 交流点灯の場合の各部波形

(1) コレクタ高圧 $V_{C E}$, 電流 $i_{c}$ 波形 $V_{C E} 20 \mathrm{~V} / \mathrm{div}, i_{\mathrm{c}} 2 \mathrm{~A} / \mathrm{div}, 10 \mu \mathrm{S} / \mathrm{div}$

(口) ランプ電压 $V_{L}$, 電流 $i_{L}$ 波形

$V_{L} 100 \mathrm{~V} / \mathrm{div}, i_{L} 0.2 \mathrm{~A} / \mathrm{div}, 10 \mu \mathrm{S} / \mathrm{div}$

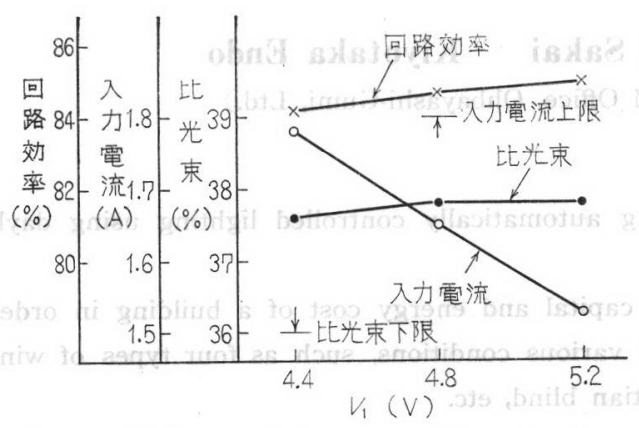

図 17 交流点灯試作回路の特性
6. おわりに

以上のように, 一石他励方式インバータにより所期の目的を達 成することができたが，ここに検討した効率改善のための各項目 は, 非常用照明の特殊性を生かしたものが多い.すなわち直流点 灯方式を用いることが可能であるのは, 点灯維持時間が 37 分以内 で短いことに加えて，点灯ひん度が小さいことによる・はたコン デンサハシラストで, コレクタ電流波形を矩形波に容易に整形でき るのは電源電圧が数ボルトで極端に低いことによる.さらにダー リントソ接続で損失の小さいスイッチング動作が可能であるの は, 低電圧トランジスタにコレタタ・エミッタ間飽和電圧が低 く, $h_{F E}$ が大きく，乙か子高周波スイッチング特性の良いもの が得られることによる.

しかし一般照明用のインバータに拈いても, 他励方式は実用化 の機運にあると考えられ, さらには点灯方式も半導体回路応用に より多様化の方向である. その推進のためには本件のようにディ ジタル ICなどの高性能素子の積極的利用と, 機種の特徵を生か した考え方による構成も必要と考光られる。

最後に本研究にご助言，ご協力いただいた日立照明(侏森山良一 課長，小山敦夫主任技師および仙葉和久企画員に深謝の意を表す る.

参 考 文 献

（1）赤塚ほか 2 名：昭54照明学会全国大会 No. 33

(2) 井山：昭55照明学会全国大会 No. 41

(3) 井山, 赤塚 : 電気学会光応用 - 視覚研究会 LAV-80-17

(4) J. Polman ほか 2 名: J. Phys, D: Appl. Phys. 5 (1972) 226

(5) 関根ほか 2 名：昭53照明学会全国大会 No. 29

（受付1980年11月 5 日）

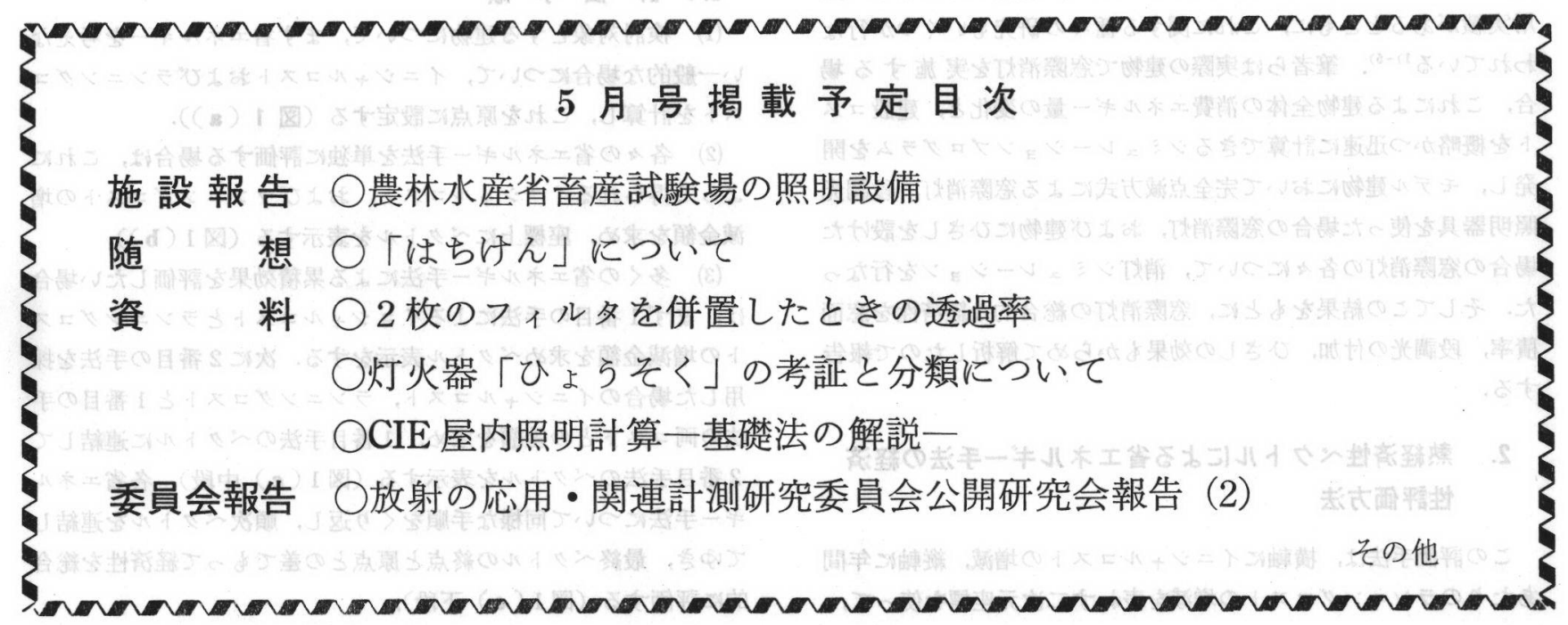

